\title{
WEIGHT LOSS DURING CIRRHOSIS IS RELATED TO THE ETIOLOGY OF LIVER DISEASE
}

\author{
Lucilene Rezende ANASTÁCIO', Lívia Garcia FERREIRA², \\ Hélem de Sena RIBEIRO ${ }^{3}$, Agnaldo Soares LIMA4 ${ }^{4}$, Eduardo Garcia VILELA ${ }^{4}$ and \\ Maria Isabel Toulson Davisson CORREIA ${ }^{4}$
}

\begin{abstract}
Context - Malnutrition is widely described in patients waiting for liver transplantation (LTx). However, risk factors associated with weight loss during liver disease have not yet been well studied. Objectives - The aim of this study was to assess weight loss and its risk factors during liver disease and up to the first appointment after transplantation. Patients who underwent LTx were retrospectively assessed for weight loss during liver disease while on the waiting list for LTx. The usual weight of the patients before disease and their weight on the first outpatient appointment after transplant were considered. Demographic, socioeconomic, lifestyle and clinical variables were collected to assess risk factors using a linear regression analysis. We retrospectively evaluated 163 patients undergoing LTx between 1997 and 2008. Results - Patients lost in average $7.7 \pm 12.4 \mathrm{~kg}$ while ill. Variables independently associated with weight loss by multiple linear regression analyses were as follows: former smoker $(P=0.03)$, greater body mass index $(P<0.01)$, overweight before liver disease $(P=0.02)$ and indication for $\operatorname{LTx}(P=0.01)$. Among these indications, patients with alcoholic cirrhosis had lost significantly more weight $(P<0.01)$, and those with hepatitis $\mathrm{C}$ virus $(P=0.01)$ and autoimmune hepatitis $(P=0.02)$ had lost significantly less weight. Conclusions - Patients experienced weight loss during liver disease independent of age, sex, schooling and income; however, the etiology of liver disease was related to weight loss.
\end{abstract}

HEADINGS - Weight loss. Liver cirrhosis, alcoholic. Liver diseases. Liver transplantation.

\section{INTRODUCTION}

Malnutrition is almost universal in patients waiting for liver transplantation $(\mathrm{LTx})^{(3)}$. Liver disease greatly impacts nutritional status because many factors of the disease contribute to a decreased food intake, such as early satiety due to ascites and gastrointestinal symptoms of nausea and vomiting ${ }^{(4)}$. Additionally, restrictive, unpalatable diets are advised despite disagreement with the current guidelines, further worsening the nutritional situation ${ }^{(9)}$. Other potential malnutrition causes include digestion and absorption abnormalities due to chronic liver failure as well as metabolic abnormalities, such as hypermetabolism, abnormal macronutrient metabolism, increased catabolic hormone secretion and decreased anabolic hormone secretion ${ }^{(8)}$.

Although malnutrition is a well-recognized condition in these patients, methods for its diagnosis are still debated due to the effects of liver disease on bio- chemical exams and body weight. Moreover, weight loss during this period is difficult to assess because ascites, edema and risk factors for these conditions have not yet been well-assessed. The aim of the current study was to evaluate weight loss and its associated risk factors in liver disease patients during the period when they are on the waiting list for transplantation.

\section{METHODS}

This was a retrospective study evaluating weight loss in LTx patients during the course of liver disease preceding transplantation. The weight before liver dysfunction (recorded from the patient interview) and the weight at the first outpatient appointment after LTx were considered (in average $23 \pm 10$ days after LTx). Risk factors for weight loss were also evaluated.

Patients who underwent transplantation due to chronic liver diseases between 1994 and 2008 and who were at least 18 years of age at LTx were followed at

Ambulatório de Transplantes, Instituto Alfa de Gastroenterologia, Hospital das Clínicas, Faculdade de Medicina, Universidade Federal de Minas Gerais, Belo Horizonte MG, Brasil.

${ }^{1}$ Adult Health Post-Graduate Program, Medical School, Universidade Federal de Minas Gerais; ${ }^{2}$ Surgery Post-Graduation Program, Medical School, Universidade Federal de Minas Gerais; ${ }^{3}$ Food Science Post-Graduation Program; Pharmacy School, Universidade Federal de Minas Gerais; ${ }^{4}$ Alfa Institute of Gastroenterology, Hospital das Clínicas, Medical School; Universidade Federal de Minas Gerais, Belo Horizonte, MG, Brasil.

Correspondence: Lucilene Rezende Anastácio - Adult Health Post-Graduation Program, Medical School, Universidade Federal de Minas Gerais. - Avenida Alfredo Balena,

110 - $5^{\circ}$ andar - 31270-901 - Belo Horizonte, MG, Brazil. E-mail: lucilene.rezende@gmail.com. 
TABLE 1. Demographic, socioeconomic, lifestyle, clinical and anthropometric characteristics of patients who underwent liver transplantation and their distribution according to weight loss

\begin{tabular}{|c|c|c|c|c|c|}
\hline \multirow{2}{*}{ Categorical parameters } & \multicolumn{2}{|c|}{ General } & \multicolumn{2}{|c|}{ Weight loss } & \multirow{2}{*}{$P$ value } \\
\hline & $\%$ & $\mathrm{n}$ & Cases & Controls & \\
\hline Male sex & 62.0 & 101 & $-9.9 \pm 13.5$ & $-4.1 \pm 9.3$ & $<0.01$ \\
\hline White as skin color & 68.7 & 112 & $-10.0 \pm 10.1$ & $-10.0 \pm 9.4$ & 0.99 \\
\hline Married & 73.0 & 119 & $-8.6 \pm 11.9$ & $-5.5 \pm 13.4$ & 0.15 \\
\hline Paid professional activity & 62.0 & 101 & $-9.5 \pm 12.5$ & $-6.3 \pm 12.2$ & 0.09 \\
\hline Smokers & 10.7 & 17 & $-9.9 \pm 11.7$ & $-7.6 \pm 12.6$ & 0.47 \\
\hline Former smokers & 40.6 & 58 & $-9.9 \pm 12.3$ & $-6.2 \pm 12.7$ & 0.08 \\
\hline \multicolumn{6}{|l|}{ Prior to liver disease } \\
\hline Arterial hypertension & 21.6 & 35 & $-6.5 \pm 13.9$ & $-8.1 \pm 12.0$ & 0.50 \\
\hline Hyperglycemia & 15.4 & 25 & $-8.2 \pm 16.4$ & $-7.6 \pm 11.6$ & 0.82 \\
\hline Diabetes mellitus & 6.8 & 11 & $-8.1 \pm 12.3$ & $-2.9 \pm 14.1$ & 0.19 \\
\hline Overweight & 46.0 & 75 & $-12.7 \pm 13.5$ & $-3.5 \pm 9.5$ & $<0.01$ \\
\hline Obesity & 17.8 & 29 & $-22.5 \pm 12.9$ & $-4.5 \pm 9.6$ & $<0.01$ \\
\hline
\end{tabular}

t Student's test

the Alfa Institute of Gastroenterology - Transplant Outpatient Clinic at Federal University of Minas Gerais, Belo Horizonte, MG, Brazil. Patients who presented with ascites in the first outpatient medical appointment after LTx were excluded from the study. Patients were interviewed once during the period of March to October 2008 to assess their demographic, socioeconomic and clinical characteristics as well as current lifestyle habits. Retrospective variables were collected from medical records. The Ethics Committee of the Federal University of Minas Gerais approved the study.

Demographic and socioeconomic data included age, sex, skin color, marital status, paid professional activity, schooling and income. Lifestyle characteristics were based on self-reported habitual hours of sleep per night, smoking habits and past smoking history. The clinical data collected were as follows: indication for LTx, presence of arterial hypertension prior to LTx, blood glucose $\geq 100 \mathrm{mg} / \mathrm{dL}$ hyperglicemia and diabetes mellitus prior to liver disease. Patients were asked about their weight before liver disease and their weight on the first outpatient appointment after LTx was collected from their medical recorders. Considering these weights, weight loss during liver disease and nutritional status were evaluated using body mass index (BMI) values (underweight if $\mathrm{BMI}<18.5 \mathrm{~kg} / \mathrm{m}^{2}$, normal weight if BMI 18.5-24.9 kg/m², overweight if BMI 24.9-29.9 $\mathrm{kg} / \mathrm{m}^{2}$, obese if BMI $>30 \mathrm{~kg} / \mathrm{m}^{2}$ ). Patients were also evaluated according to the percentage of weight loss.

Statistical analyses were performed using Statistical Package for Social Sciences version 17.0 (SPSS Inc., Chicago, IL). Numeric variables were presented as averages and standard deviations or in minimums, maximums and medians if they did not present a normal distribution (Kolmogorov-Smirnov test). Categorical variables were presented as percentages. Risk factors for weight loss were determined by univariate ( $t$ Student's test, Pearson or Spearman correlations, ANOVA) and multivariate linear regression analyses. Variables with $P<0.2$ in the univariate analysis were included in the multivariate linear regression model, which was performed using a stepwise, backward method. $P$ values $<0.05$ were considered statistically significant.

\section{RESULTS}

We evaluated 163 patients (average age at transplantation $47.7 \pm 13.3$ years, $62 \%$ male). General characteristics of patients are depicted in Table 1 . The average weight difference from the time of illness to the first outpatient appointment after transplantation was $-7.7 \pm 12.4 \mathrm{~kg}$ (median: $-6.5 \mathrm{~kg}$; minimum: $-57.8 \mathrm{~kg}$; maximum: $+28.0 \mathrm{~kg}$ ). This represented an average of $-9.5 \% \pm 15.2 \%$ of percentage of body weight loss (median: $-10.0 \%$; minimum: $-46.6 \%$; maximum: + $42.47 \%$ ). The average BMI before liver disease was $25.5 \pm$ $5.0 \mathrm{~kg} / \mathrm{m}^{2}$ and on the first outpatient appointment after LTx, $22.7 \pm 4.1 \mathrm{~kg} / \mathrm{m}^{2}$. Patients who were male, overweight or obese before liver disease lost significantly more weight (Table 1 ).

During the course of the disease, $68.7 \%(n=112)$ of patients had lost up to $5 \%$ of their usual body weight. Almost half of the patients $(48.5 \% ; n=79)$ lost up to $10 \%$. When comparing the weights recorded before liver disease to the first outpatient appointment after liver transplantation, the proportion of patients who were underweight and normal weight increased, whereas the proportion of patients who were overweight and obese decreased (Figure 1).

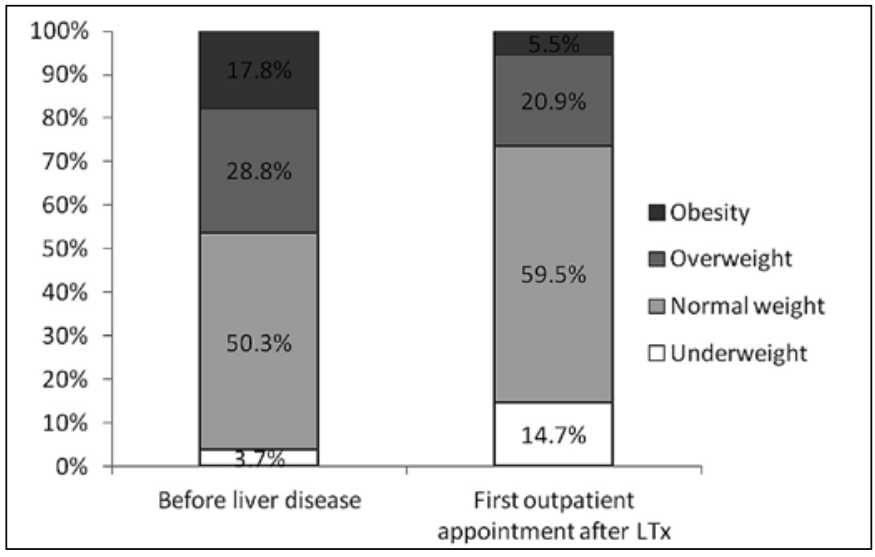

FIGURE 1. Nutritional status of patients before liver disease and on the first medical outpatient appointment after liver transplantation 
TABLE 2. Weight loss according indication for liver transplantation

\begin{tabular}{|c|c|c|c|c|}
\hline \multirow{2}{*}{ Indication for LTx } & \multicolumn{2}{|c|}{ General } & \multirow{2}{*}{$\begin{array}{c}\text { Weight loss } \\
\text { Average }\end{array}$} & \multirow{2}{*}{$P$ value } \\
\hline & $\%$ & $\mathrm{n}$ & & \\
\hline Alcohol abuse & 30.1 & 49 & $-10.8 \pm 14.2^{\mathrm{a}, \mathrm{b}}$ & \\
\hline Auto-immune hepatitis & 10.4 & 17 & $-1.9 \pm 13.2^{\mathrm{c}, \mathrm{d}}$ & \\
\hline Cryptogenic cirrhosis & 11.7 & 19 & $-11.7 \pm 14.1^{\mathrm{a}, \mathrm{b}}$ & 0.02 \\
\hline Hepatitis $C$ virus & 33.1 & 54 & $-5.0 \pm 10.4^{c, d}$ & \\
\hline Others & 22.7 & 37 & $-8.9 \pm 7.9^{b}$ & \\
\hline
\end{tabular}

ANOVA and $t$ Student's test;

a significantly different when comparing patients with hepatitis $C$ virus indication for LTx;

${ }^{\mathrm{b}}$ significantly different when comparing patients with autoimmunity hepatitis as indication for LTx

'significantly different when comparing patients with alcoholic abuse as indication for LTx:

d significantly different when comparing patients with cryptogenic cirrhosis as indication for LTx

Numerical variables that were correlated with weight loss were as follows: age at transplant $(\mathrm{r}=-0.19 ; P=0.02)$ and BMI before liver disease $(\mathrm{r}=-0.63 ; P<0.01)$. Schooling (median 10 years of schooling, range $0-17$ years) and income per capita per month (median U\$500, range U\$83-U\$6,000) were not correlated with weight loss $(P>0.05)$.

Variables independently associated with weight loss by multivariate linear regression analyses were as follows: former smoker $(P=0.03)$, greater BMI $(P<0.01)$, overweight before liver disease $(P=0.02)$ and indication for liver transplantation $(P=0.01)$. Among these indications, patients with alcoholic cirrhosis had lost significantly more weight $(P<0.01)$, and those with hepatitis $C$ virus $(P=0.01)$ and autoimmune hepatitis $(P=0.02)$ had lost significantly less weight (Table 2$)$.

\section{DISCUSSION}

In this study, the average weight difference from the time of illness to the first outpatient appointment after transplant was $-7.7 \pm 12.4 \mathrm{~kg}$ (median: $-6.5 \mathrm{~kg}$; minimum: $-57.8 \mathrm{~kg}$; maximum: $+28.0 \mathrm{~kg}$ ). Malnutrition is present in almost all patients waiting for $\mathrm{LTx}^{(3)}$; however, weight loss is difficult to measure in this period as patients often present with ascites and edema. We have no knowledge of any study that evaluated weight loss during liver disease that accounted for excess body water due to ascites and edema. However, the current study has many limitations, including the fact that it was based on patient-reported information of weight before liver disease. Additionally, we were unable to access information about the duration of liver disease and its severity as well as food intake during the liver disease period.

Weight loss occurred independently of sex, age, marital status, schooling and income. Weight loss was also analyzed according to the etiology of liver disease, and those with alcohol abuse lost significantly more weight $(-10.8 \pm 14.2 \mathrm{~kg})$ than others. Alcoholic cirrhosis has been associated with a worse nutritional status in some studies ${ }^{(1)}$ but not in others $^{(5)}$. Heavy drinkers and those with alcoholic cirrhosis generally have a poor diet. Furthermore, alcohol toxicity contributes to poor nutritional status by interfering with the absorption, transportation and utilization of essential nutrients ${ }^{(11)}$, which may worsen weight loss in these patients.
Patients who were transplanted because they had the hepatitis $C$ virus $(-5.0 \pm 10.4 \mathrm{~kg})$ and autoimmune hepatitis $(-1.9 \pm 13.2 \mathrm{~kg})$ lost less weight than other patients. The corticosteroids used in the treatment of auto-immune hepatitis could be related to this observation, as they could enhance appetite and stimulate the intake of sweet and high fat diets ${ }^{(2)}$. However, further studies are required to assess this effect.

Patients who were overweight and/or had greater BMI before liver disease lost more weight. How the nutritional status of these patients could have been more affected by liver disease has not been documented yet. A potential hypothesis for this effect relates to the higher surgical/intensive care morbidity among obese patients ${ }^{(10)}$, leading to a longer hospital stay and deterioration of nutritional status after transplantation ${ }^{(7)}$. This aspect is another great limitation of the current study, as it was not assessed.

Smoking cessation is largely associated with weight gain in the general population, as it increases energy intake, decreases resting metabolic rate, decreases physical activity and increases lipoprotein lipase activity ${ }^{(6)}$. However, explanations as to why former smokers lose more weight during liver disease also require further investigation.

In conclusion, our data indicate that patients lost weight during liver disease independently of age, sex, schooling and income. However, the etiology of liver disease was related to the extent of these losses, as evidenced by greater weight loss in those with alcoholic cirrhosis and lower weight loss in those with cirrhosis due to hepatitis $\mathrm{C}$ viral infections and autoimmune hepatitis. Patients with a higher BMI, who were overweight and who were former smokers also presented with increased weight loss.

\section{ACKNOWLEDGEMENTS}

We thank Conselho Nacional de Desenvolvimento Científico e Tecnológico (CNPq) for the grant to MITDC, Comissão de Aperfeiçoamento em Nível Superior (CAPES) for the grant to LRA and HSR and Fundação de Amparo à Pesquisa de Minas Gerais (FAPEMIG) for the grant to LGF. We also thank Pró-Reitoria de Pesquisa da Universidade Federal de Minas Gerais for their support in language reviewing. 
Anastácio LR, Ferreira LG, Ribeiro HS, Lima AS, Vilela EG, Correia MITD. Perda de peso durante a cirrose está relacionada à causa da doença hepática. Arq Gastroenterol. 2012;49(3):195-8.

RESUMO - Contexto - A desnutrição é amplamente descrita em pacientes à espera de transplante hepático (LTx). No entanto, fatores de risco associados à perda de peso durante a doença do fígado ainda não foram bem estudados. Objetivos - Avaliar a perda de peso e seus fatores de risco durante a doença do fígado e até a primeira consulta após o transplante. Pacientes submetidos ao LTx foram retrospectivamente avaliados para perda de peso durante a doença do fígado, enquanto na lista de espera para LTx. O peso usual dos pacientes antes da doença e seu primeiro peso ambulatorial após o transplante foram considerados para as análises. Variáveis demográficas, de estilo de vida, socioeconômicas e variáveis clínicas foram coletadas para avaliar fatores de risco, usando análise de regressão linear múltipla. Resultados - Foram avaliados retrospectivamente 163 pacientes submetidos a LTx entre 1997 e 2008. Os pacientes perderam em média 7,7 $\pm 12,4 \mathrm{~kg}$, quando doentes. Variáveis independentemente associadas à perda de peso foram as seguintes: ex-fumante $(P=0,03)$, maior índice de massa corporal $(P<0,01)$, excesso de peso antes de doença hepática $(P=0,02)$, indicação ao transplante $(P=0,01)$. Das indicações ao transplante, os indivíduos que foram diagnosticados com cirrose etanólica perderam significantemente mais peso $(P<0,01)$ e os diagnosticados com hepatite viral C $(P=0,01)$ e hepatite autoimune $(P=0,02)$, significantemente menos. Conclusões - Os pacientes estudados apresentaram perda de peso durante a doença do fígado independentemente da idade, sexo, escolaridade e renda, no entanto, a causa da doença hepática esteve relacionada à perda de peso.

DESCRITORES - Perda de peso. Cirrose hepática alcoólica. Hepatopatias. Transplante de fígado.

\section{REFERENCES}

1. Caly WR, Strauss E, Carrilho FJ, Laudanna AA. Different degrees of malnutrition and immunological alterations according to the aetiology of cirrhosis: a prospective and sequential study. Nutr J. 2003; Oct 7:2-10.

2. Dallman MF, la Fleur SE, Pecoraro NC, Gomez F, Houshyar H, Akana SF. Minireview: glucocorticoids--food intake, abdominal obesity, and wealthy nations in 2004. Endocrinology. 2004;145:2633-8.

3. Ferreira LG, Anastacio LR, Correia MI. The impact of nutrition on cirrhotic patients awaiting liver transplantation. Curr Opin Clin Nutr Metab Care. 2010;13:554-61.

4. Ferreira LG, Anastacio LR, Lima AS, Correia MI. [Malnutrition and inadequate food intake of patients in the waiting list for liver transplant]. Rev Assoc Med Bras. 2009;55:389-93.

5. Ferreira LG, Anastacio LR, Lima AS, Correia MI. Assessment of nutritional status of patients waiting for liver transplantation. Clin Transplant. 2011;25:248-54.
6. Filozof C, Fernandez Pinilla MC, Fernandez-Cruz A. Smoking cessation and weight gain. Obes Rev. 2004;5:95-103.

7. Hade AM, Shine AM, Kennedy NP, McCormick PA. Both under-nutrition and obesity increase morbidity following liver transplantation. Ir Med J. 2003;96:140-2.

8. Henkel AS, Buchman AL. Nutritional support in patients with chronic liver disease. Nat Clin Pract Gastroenterol Hepatol. 2006;3:202-9.

9. Heyman JK, Whitfield CJ, Brock KE, McCaughan GW, Donaghy AJ. Dietary protein intakes in patients with hepatic encephalopathy and cirrhosis: current practice in NSW and ACT. Med J Aust. 2006;185:542-3.

10. Kiraly L, Hurt RT, Van Way CW, 3rd. The outcomes of obese patients in critical care. JPEN J Parenter Enteral Nutr. 2011;35(5 Suppl):29s-35s.

11. Lieber CS. Relationships between nutrition, alcohol use, and liver disease. Alcohol Res Health. 2003;27:220-31.

Received 26/1/2012 Accepted 26/3/2012 